\title{
Small and Medium Enterprises and Global Risks: Evidence from Manufacturing SMEs in Turkey
}

\author{
Ali Asgary ${ }^{1}$ Ali Ihsan Ozdemir ${ }^{2} \cdot$ Hale Özyürek ${ }^{3}$
}

Published online: 12 February 2020

(C) The Author(s) 2020

\begin{abstract}
This study investigated how small and medium enterprises (SMEs) in a country perceive major global risks. The aim was to explore how country attributes and circumstances affect SME assessments of the likelihood, impacts, and rankings of global risks, and to find out if SME risk assessment and rankings differ from the global rankings. Data were gathered using an online survey of manufacturing SMEs in Turkey. The results show that global economic risks and geopolitical risks are of major concern for SMEs, and environmental risks are at the bottom of their ranking. Among the economic risks, fiscal crises in key economies and high structural unemployment or underemployment were found to be the highest risks for the SMEs. Failure of regional or global governance, failure of national governance, and interstate conflict with regional consequences were found to be among the top geopolitical risks for the SMEs. The SMEs considered the risk of largescale cyber-attacks and massive incident of data fraud/theft to be relatively higher than other global technological risks. Profound social instability and failure of urban planning were among the top societal risks for the SMEs. Although the global environmental and disaster risks were ranked lowest on the list, man-made environmental damage and
\end{abstract}

Ali Asgary

asgary@yorku.ca

1 Disaster and Emergency Management, School of Administrative Studies, York University, Toronto, ON M3J 1P3, Canada

2 Business Administration Department, Business School, Ankara Yıldırım Beyazıt University, Esenboğa Campus, Ankara, Turkey

3 KOSGEB (Small and Medium Industry Development Organization), Ankara, Turkey disasters and major natural hazard-induced disasters were ranked the highest among this group of risks. Overall, the results show that SMEs at a country level, for example Turkey, perceive global risks differently than the major global players.

Keywords Global risks · Risk assessment - Risk matrix $\cdot$ Small and medium enterprises - Turkey

\section{Introduction}

Small and medium enterprises (SMEs) face many small and large internal and external risks. While they can better control much of the internal risks through risk management and treatment measures, they are more vulnerable to external risks because these risks are often beyond their control, influence, radar, and capacity to manage. The World Economic Forum (WEF) has created, assessed, and monitored 30 global risks since 2005, using a survey of about 1000 major global stakeholders and players. By the WEF definition, a global risk is "an uncertain event or condition that, if it occurs, can cause significant negative impact for several countries or industries within the next 10 years" (World Economic Forum 2019, p. 100).

Small and medium enterprises are playing a vital role in local, national, and global economies and are very important in job and income generation (Chowdhury 2011; OECD 2014; Chatterjee et al. 2015). At least $90 \%$ of the firms in both developed and developing countries are SMEs (Mbuyisa and Leonard 2017). They account for 40-60\% of GDP in developed and developing countries (Igwe et al. 2018) and generate about $40 \%$ of the global industrial production and $35 \%$ of the world's exports (Sharma and Bhagwat 2006; Mbuyisa and Leonard 2017). Small and 
medium enterprises are the backbone of the European economy, with more than $99.8 \%$ of all non-financial businesses, $58 \%$ of total value added, and $66.8 \%$ of total employment (Briozzo and Cardone-Riportella 2012; European Commission 2015). In Japan, more than $99.7 \%$ of all firms are SMEs, they employ more than $70 \%$ of the workforce, and create more than $50 \%$ of all added value of the manufacturing industry (Yoshino and Taghizadeh-Hesary 2018). Small and medium enterprises comprised $99.8 \%$ of the firms in Turkey in 2014 and were involved in $55.1 \%$ of export and $37.7 \%$ of import (Kaya and Uzay 2017). Considering their size and roles in the national and global economies and the fact that the enhancement of the private sector's resilience depends on risk reduction by SMEs (Chatterjee et al. 2015), more studies are needed to better understand various aspects of SME risk management.

Small and medium enterprises, like large corporations, face a significant number of risks, and their survival and resilience are important for national and global economies. However, SMEs are less prepared to manage the risks, and the institutional supports for them are rather weak (Han and Nigg 2011). Small and medium enterprises around the world, particularly in developing and emerging economies do not have strong risk management, business continuity, and crisis management cultures and systems in place (Asgary et al. 2013; Yuwen et al. 2016; Kaya and Uzay 2017). Most of SMEs not have the resources and expertise to focus on these activities and therefore are more vulnerable to internal and external risks and disruptive shocks (Leopoulos et al. 2006; Marks and Thomalla 2017). To minimize the impacts, it is important that SMEs become more aware of global risks, as well as assess, monitor, and enhance their risk management and business continuity management capacities (Güneş and Teker 2010; Brustbauer 2016; Kaya and Uzay 2017).

The goals of this study were twofold: (1) to examine whether country attributes and circumstances affect SME assessments of the likelihood, impacts, and rankings of global risks; and (2) to find out if SME risk assessment and rankings differ from global rankings. Small and medium enterprises in manufacturing in an emerging economy with global footprints were selected because, unlike the WEF that takes its samples from large international players, the sample SMEs are small individual players in the global economy and it is important to see how they view the global risks.

\section{Small and Medium Enterprises and Global Risks}

The 2019 Global Risk Report by the World Economic Forum (WEF 2019) examines 30 important global risks that are classified into five categories: economic,
Table 1 The thirty global risks identified by the World Economic Forum. Source: World Economic Forum (WEF 2019)

\begin{tabular}{|c|c|}
\hline $\begin{array}{l}\text { Risk } \\
\text { categories }\end{array}$ & Risks \\
\hline Economic & $\begin{array}{l}\text { Asset bubbles in a major economy } \\
\text { Deflation in a major economy } \\
\text { Failure of a major financial mechanism } \\
\text { Failure/shortfall of critical infrastructure } \\
\text { Fiscal crises in key economies } \\
\text { High structural unemployment or underemployment } \\
\text { Illicit trade } \\
\text { Severe energy price shock } \\
\text { Unmanageable inflation }\end{array}$ \\
\hline Environmental & $\begin{array}{l}\text { Extreme weather events } \\
\text { Failure of climate-change mitigation and adaptation } \\
\text { Major biodiversity loss and ecosystem collapse } \\
\text { Major natural disasters } \\
\text { Man-made environmental damage and disasters }\end{array}$ \\
\hline Geopolitical & $\begin{array}{l}\text { Failure of national governance } \\
\text { Interstate conflict with regional consequences } \\
\text { Failure of regional or global governance } \\
\text { Large-scale terrorist attacks } \\
\text { State collapse or crisis } \\
\text { Weapons of mass destruction }\end{array}$ \\
\hline Societal & $\begin{array}{l}\text { Failure of urban planning } \\
\text { Food crises } \\
\text { Large-scale involuntary migration } \\
\text { Profound social instability } \\
\text { Rapid and massive spread of infectious diseases } \\
\text { Water crises }\end{array}$ \\
\hline Technological & $\begin{array}{l}\text { Adverse consequences of technological advances } \\
\text { Breakdown of critical information infrastructure and } \\
\text { networks } \\
\text { Large-scale cyber-attacks } \\
\text { Massive incident of data fraud/theft }\end{array}$ \\
\hline
\end{tabular}

environmental, geopolitical, societal, and technological (Table 1). These risks are evaluated annually based on 1000 global players and stakeholder views of the risks.

According to the 2019 WEF global risk report, extreme weather events, failure of climate-change mitigation and adaptation, natural disasters, data fraud or theft, cyber-attacks, man-made environmental damages and disasters, large-scale involuntary migration, biodiversity loss and ecosystem collapse, water crises, and asset bubbles in a major economy were ranked the top 10 global risks in terms of likelihood. Weapons of mass destruction, failure of climate-change mitigation and adaptation, extreme weather events, water crises, natural disasters, biodiversity loss and ecosystem collapse, cyber-attacks, critical information infrastructure breakdown, man-made 
environmental damages and disasters, and spread of infectious diseases were the top 10 global risks in terms of impacts. In both cases, three out of five environmental risks are among the top five risks and all five of them are in the top 10 risks (WEF 2019).

\subsection{Small and Medium Enterprises and Global Economic Risks}

Global economic risks have significant implications for SMEs, particularly those in the manufacturing sector. Asset bubbles in a major economy can increase the production costs through inflation, wage increases and labor shortages, and access to financial resources that will impact the global economy (Zheng et al. 2010). Global financial crises cause substantial downturn in the formation of new SMEs, their performance, and their existence in the market. The 1997-1998 world financial and economic crisis severely impacted SMEs. As interest rates started to rise, many SMEs were bankrupted due to the credit crunch, tight monetary policies, and decline in domestic and international demands (Filardo 2011; Wehinger 2014). The number of bankrupted SMEs in South Korea, for example, particularly in the manufacturing sector, increased by nearly $100 \%$ from 1996 to 1998 (Gregory et al. 2002).

The 2008 economic crisis induced severe socioeconomic impacts worldwide and impacted SMEs in almost every economy, far beyond expectations, through fast domino effects that caused massive SME closures, downsizing, and reduced the number of new ventures (Chowdhury 2011; Sannajust 2014). Small and medium enterprises were under extreme pressures and experienced devastating decrease in demand and revenues, increased lay-offs, and stressful working environments (Kossyva et al. 2014). Close to $50 \%$ of the SMEs in Belgium and the Netherlands, for example, experienced extended delays in their receivables (Kossyva et al. 2014). Small and medium enterprises in the United States lost 2.8 million jobs (Gagliardi et al. 2013). During this global turmoil, Turkish SMEs were also impacted heavily (Karadag 2016).

During an economic crisis, SMEs are more vulnerable because of weak cash flow and financial structures, low equity reserves, limited adaptation potential and flexibility for downsizing, liquidation problems, too much dependency on external financial resources, tightened credit lines, payment delays on receivables, lack of resources, and lack of necessary skills to adopt or make necessary strategic decisions (Ates et al. 2013; Sannajust 2014; Wehinger 2014; Karadag 2016).

Failure of aging and insecure energy, transportation, and communications infrastructure can have major short- and long-term risks for SME performance and competitiveness. High structural unemployment lowers demand for goods and services and impacts SMEs significantly (Alegre and Chiva 2013). Illicit trade reduces SME competitiveness in the global market. In countries with higher levels of economic risk, SMEs have less of a chance to flourish (Mekinc et al. 2013). Energy is an important input for SME production and logistics. If energy prices are not manageable or controlable, SMEs face major uncertainties about energy costs and availability (Mulhall and Bryson 2014). Energy price shocks raise SME production costs (Kilian 2008) and compromise their individual and collective competitiveness in the global economy. It is mainly because SMEs are usually less flexible with respect to their energy sources and SMEs in the manufacturing sector are very energy intensive, that unpredicted fluctuations in energy prices impact them extensively. Energy price shock events have become more frequent and a consistent feature of the energy markets in recent years (Mulhall and Bryson 2014). As the global demand for energy increases, more shock events in the energy prices are expected. Finally, unmanageable high inflation rates at national and global levels pose risks to SMEs through higher interest rates (Cefis and Marsili 2006; Gül et al. 2010).

\subsection{Small and Medium Enterprises and Global Environmental and Disaster Risks}

Small and medium enterprises around the globe, particularly those that are part of the global supply chains, are exposed to various types of global environmental and disaster risks that can have devastating impacts on SMEs (Auzzir et al. 2018). These enterprises are highly vulnerable to and not well prepared for most of the global environmental and disaster risks (Crichton 2006; Schaefer et al. 2011). They are vulnerable to environmental disaster risks on four fronts: capital, labor, logistics, and markets (Ballesteros and Sonny 2015). Environmental and disaster risk events can damage and disrupt the supply chain networks in which many SMEs are embedded. They can also damage SME assets, premises, and inventories, disrupt their operations, increase their production costs, and reduce their revenues and long-term growth potentials (Snyder and Shen 2006; Linnenluecke and Griffiths 2010, 2012; Asgary et al. 2012). Small and medium enterprises have limited capabilities to recover from these events and bring their operations, revenue, and profit back to pre-event conditions (Asgary et al. 2013). Considering the links that exist between climate change and extreme events, it is expected that these events will increase in the future (IPCC 2013). Small and medium enterprises face significant climate change-related environmental and regulatory risks (Schaefer et al. 2011). Major costly floods, severe heat and cold waves, heavy rains and extreme storms with higher frequency and intensity are observed globally. Extreme 
events not only cause disruptions and destruction to SMEs, but also create major challenges for their continuity of operations and future planning (Gunawansa and Kua 2014; Gasbarro et al. 2018). Studies show that few SMEs are adequately prepared for disaster risks. Small and medium enterprises are among the top underinsured sectors, and they usually do not conduct risk assessments or have business continuity plans (Wedawatta et al. 2010; Ye and Abe 2012). The 2011 floods in Thailand, for example, had major impacts on SMEs, and approximately 550,000 SMEs experienced direct and indirect damages, estimated at 71.1 billion Thai Baht per month, with 2.32 million jobs lost (Ye and Abe 2012). The 2011 Great East Japan Earthquake and the Thailand floods demonstrated that natural hazard-induced disasters can seriously inhibit the development of SMEs (Ye and Abe 2012; Auzzir et al. 2018).

Studies show that overall about $25 \%$ of SMEs do not reopen following a major disaster (Ballesteros and Sonny 2015). Of the US companies that experience disasters, for example, $43 \%$ never reopen, and another $29 \%$ close within 2 years (Weinhofer and Busch 2013; Ballesteros and Sonny 2015). Small and medium enterprises are worse off after disaster events compared to before disaster because they are relatively resource constrained, less resilient, are mainly informal and some of them do not fully comply or are not requested to follow standards and codes, lack necessary insurance, do not carry out risk assessments, and are often without business continuity plans (Ye and Abe 2012; UNDP 2013; Ballesteros and Sonny 2015; Halkos et al. 2018).

Being prone to multiple natural hazards such as flooding, earthquakes, and drought, natural hazards and disasters have affected SMEs in Turkey as well. The 1999 earthquake had significant economic impacts on the enterprise sector, ranging from USD 1.1 to 4.5 billion in damages (OECD 2000), most of it from the loss in manufacturing (USD 600 to 700 million). About $63.2 \%$ of the total manufacturing industry were damaged in five provinces, and 31,000 SMEs suffered heavy physical damages. Ezgi (2014) reported that the vast majority of SMEs had little preparedness before the earthquake and only $30 \%$ of them invested in insurance before the earthquake.

\subsection{Small and Medium Enterprises and Global Geopolitical Risks}

A world of geopolitical instability and uncertainty is a major concern for all sectors and businesses, but more so for SMEs. Many of these risks are cross border with global consequences. While existing international political and economic agreements such as those of the World Trade Organization (WTO) are weakened by unilateralism, there is little evidence that new and better multilateralism agreements are replacing them (Pascual-Ramsay 2015; Asgary and Ozdemir 2019). Rather these agreements are being replaced by fragmentation, bilateralism, regionalism, as well as local and short-term interests (Pascual-Ramsay 2015; Asgary and Ozdemir 2019). The international economy and its key players, including SMEs, are becoming more exposed and vulnerable to existing and emerging geopolitical risks and uncertainties (PascualRamsay 2015).

Studies show that terrorist attacks, for example, even though they are very small in terms of direct physical impact zones, have economic impacts that are often substantial and very extensive. Repeated terrorist attacks in one country not only impact the economy of that country but create spillover impacts for neighboring countries and the global economy. Terrorist attacks discourage foreign investments and capital inflows and cause significant loss of economic activities and international trade (Abadie and Gardeazabal 2008; Araz-Takay et al. 2009). These risks can also increase insurance, transaction, transportation, and security costs for SMEs.

Turkey as an emerging economy located in a geopolitically complex region (Middle East and North Africa), with several potentially failing neighboring states, and as a member of various types of regional agreements, has a unique situation in terms of geopolitical risks. Turkey has been suffering from terrorism and dealing with regional conflicts, both of which have had various impacts on the SMEs. The presence of terrorist activities has impacted the emergence and growth of SMEs and the overall economic performance in the country. Bilgel and Karahasan (2017) found that after the rise of terrorism, the per capita real GDP in Eastern and Southeastern Anatolia declined by about $6.6 \%$. Other studies also found that terrorism has a major negative impact on foreign direct investments in Turkey (Omay et al. 2013).

\subsection{Small and Medium Enterprises and Global Societal Risks}

Global societal risks have specific implications for SMEs. Failure of urban planning leads to declining cities, informal urban growth or sprawl, and poor and fragile infrastructure with significant social, environmental, and health issues (Asgary and Ozdemir 2019). Such urban environments are not able to adequately support enterpreneurship activities that can compete at national and global levels. Cities without efficient and interconnected transportation systems, with significant air pollution, and unaffordable land and housing prices are not attractive for entrepreneurship growth (TURSAB and TUADER 2017). But SME engagement in risk management and critical infrastructure protection is an effective way to reduce the impact of 
future disasters in urban areas (Chatterjee et al. 2015; Chatterjee et al. 2016). Food and water crises are other important global risks that can affect SMEs in several ways, particularly those in the agri-food business and those that are in water-intensive manufacturing sectors. Social instability as another global risk is not healthy for SME growth and competitiveness. Global pandemics such as the 2003 Severe Acute Respiratory Syndrome (SARS) pandemic and the 2009 H1N1 pandemic can have immediate direct and indirect impacts on SMEs. For example, SARS had major impacts on SMEs, particularly those in the tourism and hospitality sector in heavily impacted countries such as China, Canada, Thailand, and Hong Kong (Kuo et al. 2008). Studies have found that many SMEs do not recognize pandemics as a meaningful risk. Although governments have tried to raise awareness and provide resources to enhance pandemic preparedness by SMEs, awareness or concern and actual preparedness have not changed much, and most SMEs do not have appropriate preparedness and continuity plans for future pandemics (Watkins et al. 2008). Armed conflicts, interstate wars, natural hazards and disasters, and climate change are creating widespread involuntary and forced displacement around the globe. Population displacements have a range of economic, social, and political impacts on both source and host countries (Tumen 2016; Salgado-Gálvez 2018). The impacts of forced migration on SMEs have not been studied yet, but it may have both positive and negative impacts. At least SMEs can be considered a solution for some of these problems by providing job opportunities for displaced people. Turkey has received more than 4 million displaced people from Syria since the start of conflict in 2012 (Onur 2018).

\subsection{Small and Medium Enterprises and Global Technological Risks}

Adverse consequences of technological advances could be very diverse and consequential for SMEs, especially those in the manufacturing sector. New technologies such as robotics, autonomous vehicles and drones, automation, smart phones, artificial intelligence, 3-D printing, cloud computing and big data, and new materials are among the new technologies that can have unintended consequences and risks for manufacturing SMEs. These technologies have the potential to reduce outsourcing. Studies predict that $47 \%$ of the jobs in the United States (much of them in SMEs) are at high risk of being automated over the next 20 years, especially in manufacturing, logistics, and administrative support (Pascual-Ramsay 2015). These advances will possibly reduce employment opportunities for workers in manufacturing SMEs and will challenge SMEs survival.
While information technology brings significant growth opportunities for SMEs through knowledge and information availability, business communication, cost savings and efficiency, improving decision making, responsiveness, and overall flexibility (Mbuyisa and Leonard 2017), technology also introduces risks, including data theft, disruptions, and cyber-attacks (Chacko and Harris 2006). Like other institutions, SMEs are dependent on internet and information technology and a substantial number of their sales and orders are handled through cyberspace and networks. Any major failure and disruption of the national and global information infrastructure and networks due to large-scale disaster events can have significant negative impacts on SMEs. Such disruptions can have severe consequences for SMEs that are very vulnerable and without adequate protection. Small and medium enterprises use these technologies in production and service delivery, distribution, sales, and marketing. Data breaches, cyber security, and intentional or accidental technological failures can disrupt or significantly damage the short- and long-term operation as well as the existence of SMEs.

\section{Methodology and Data}

Following the WEF (2019), this study uses a qualitative risk assessment (QRA) approach. This will allow us to compare the results of the study with the global risk report results. Qualitative risk assessment is one of the most widely used risk assessment approaches because of its low cost and ease of use and it is quick to perform (Modarres 2006). In QRA, potential likelihoods and consequences are assessed using qualitative scales such as low, medium, and high. Qualitative risk assessment uses subjective likelihood and consequence values collected from experts and decision makers and, as such, they are not always perfect estimates and are subject to biases and heuristics (Talbot 2011). Assessed likelihoods and consequences for selected risks are then ploted in a two-dimensional space to generate a risk matrix. Various risk matrix forms and sizes have been reported in risk assessment reports. A risk matrix is used to visualize, compare, and rank different risks based on their locations in the matrix. Color coding is mostly used to show the importance of each risk. The risk matrix approach is also used for indicating possible risk control measures and to record the inherent, current, and target levels of risk (Hopkin 2012).

A risk matrix provides some basis for risk treatments and management. Risks that are located in the top righthand corner of the risk matrix (often colored in red) have higher likelihoods and impacts. These risks are very critical and need to be controled. Risks that are in the lower (colored in green) and middle part (colored in orange or 
yellow) of the matrix should be monitored and checked regularly. Although the risk matrix method has been criticized by scholars and professionals (Cox 2008; Ni et al. 2010; Bao et al. 2017), it is an invaluable tool for fast, effective, and practical risk assessment (Talbot 2011).

Data were collected from a sample of manufacturing SMEs in Turkey. Small and medium enterprises in Turkey are categorized into three groups of micro, small, and medium-sized enterprises based on their employee numbers and annual revenues. Micro firms are those with less than 10 employees and less than USD 430,000 annual turnover. Small firms are those with less than 50 employees and less than USD 3.4 million annual turnover, and medium-sized firms are those with less than 250 employees and less than USD 17.2 million annual turnover (Karadag 2016).

To assess and evaluate the risks, a questionnaire survey, including 19 questions, was developed. Several questions collected general information about the production type, years in operation, city of operation, position of responder in the business, percent of production for export, percent of imported production materials, and export countries. In two sets of questions SME representatives provided their opinion about the consequences and likelihoods of global risks. Samples of a risk likelihood question and a risk consequences question are:

6. Review the following global economic risks and give your opinion on the likelihood of these risks occurring in the manufacturing sector in Turkey over the next 10 years.

- Critical infrastructure failure:

- very unlikely

- unlikely

- somewhat likely

- likely

- very likely

7. Please review the following global economic risks and give your opinion about the potential impacts/consequences of these risks on the manufacturing sector in Turkey over the next 10 years.

- Critical infrastructure failure:

- minimal

- minor

- moderate

- severe

- catastrophic

The questionnaire was designed and distributed using Google Form. Small and medium enterprises operating in the manufacturing sector (NACE Revision.02 in C Class through 10-33) were included in the population framework. These are SMEs in the NACE classes that are registered with the KOSGEB (Small and Medium Industry Development Organization, Turkey) and had an approved KOBI (SME) certificate in 2017. The survey link was emailed to about 40,000 SMEs on 19 April 2019. Potential respondents were asked to complete the online survey by 3 May 2019. By the deadline, 217 completed responses had been received.

\subsection{Basic Characteristics of the Sample Small and Medium Enterprises}

The sample covers SMEs in different manufacturing areas. After the unspecified "Other" manufacturing subgroup (39), SMEs in food products (22), textiles (22), machinery and equipment (22), furniture (20), fabricated metal (13), basic metal (9), wood products (9), rubber and plastic (9), electrical equipment (8), and chemical products (8) had the highest number of participants in this study. The questionnaire was completed by various individuals within each sample business, including managers (36), owners (20), accounting managers (13), financial managers (9), business partners (10), board members (3), engineers (6), and other employees (9). Sample SMEs are operating in 50 different cities and 7 geographic regions in Turkey, including Marmara (72), Central Anotolia (47), Aegean (29), Black Sea (24), Mediterranean (23), Eastern Anotolia (11), and Southeastern Anotolia (11).

The majority of the sample businesses (132) have been in operation for less than 10 years, only 34 have been in operation for 11 to 20 years, 29 between 21 and 30 years, and the rest (22) have been in business for more than 31 years. About $39.6 \%$ of the sample businesses were micro businesses, $37.8 \%$ small businesses, and about $22.6 \%$ were medium-sized enterprises. More than $60 \%$ of the SMEs export their products to varying degrees. They export to a large list of neighboring and European countries in particular. The sample SMEs also import some of their raw materials and equipment, and about $85 \%$ use imported products in their productions.

\section{Findings}

Using the methodology on collected data respondents perceived likelihood of the global risks and their impacts were identified and risk values were calculated, and risk matrix was generated using the risk values. This section presents the key findings. 


\subsection{Perceived Likelihood of Global Risks and their Impacts}

Almost all global economic risks are perceived to have very high and high likelihoods by the sample Turkish SMEs (Fig. 1a). However, fiscal crises in key economies, high structural unemployment or underemployment, and severe energy price shock are among the most likely risks according to the sample enterprises. A majority of the SMEs thought that catastrophic and severe impacts can be expected from the economic risks, particularly unmanageable inflation, high structural unemployment or underemployment, and fiscal crises in key economies (Fig. 1b).

Global environmental risks seem to have relatively lower likelihoods to the sample SMEs, compared with the global economic risks (Fig. 2a). Man-made environmental damages caused by human and major natural hazards and disasters show higher perceived likelihood. The perceived impacts from these risks were scored lower as well. Among these risks, environmental damages caused by human are perceived to have slightly higher impacts for the sample businesses (Fig. 2b).

Figure $3 \mathrm{a}$ and $\mathrm{b}$ show the sample SME respondents' opinion about the likelihoods and the consequences of the global geopolitical risks. Failure of national governance and failure of regional or global governance, and largescale terrorist attacks have the highest average perceived likelihood in this risk category. However, the impacts are assessed to be higher for interstate conflicts with regional consequences, followed by the failure of national governance, and failure of regional or global governance.

Among global societal risks failure of urban planning and profound social instability were perceived to have the highest likelihood and impact averages among the sample businesses (Fig. 4a, b). While water crises seem to have a high perceived likelihood, sample businesses on average do

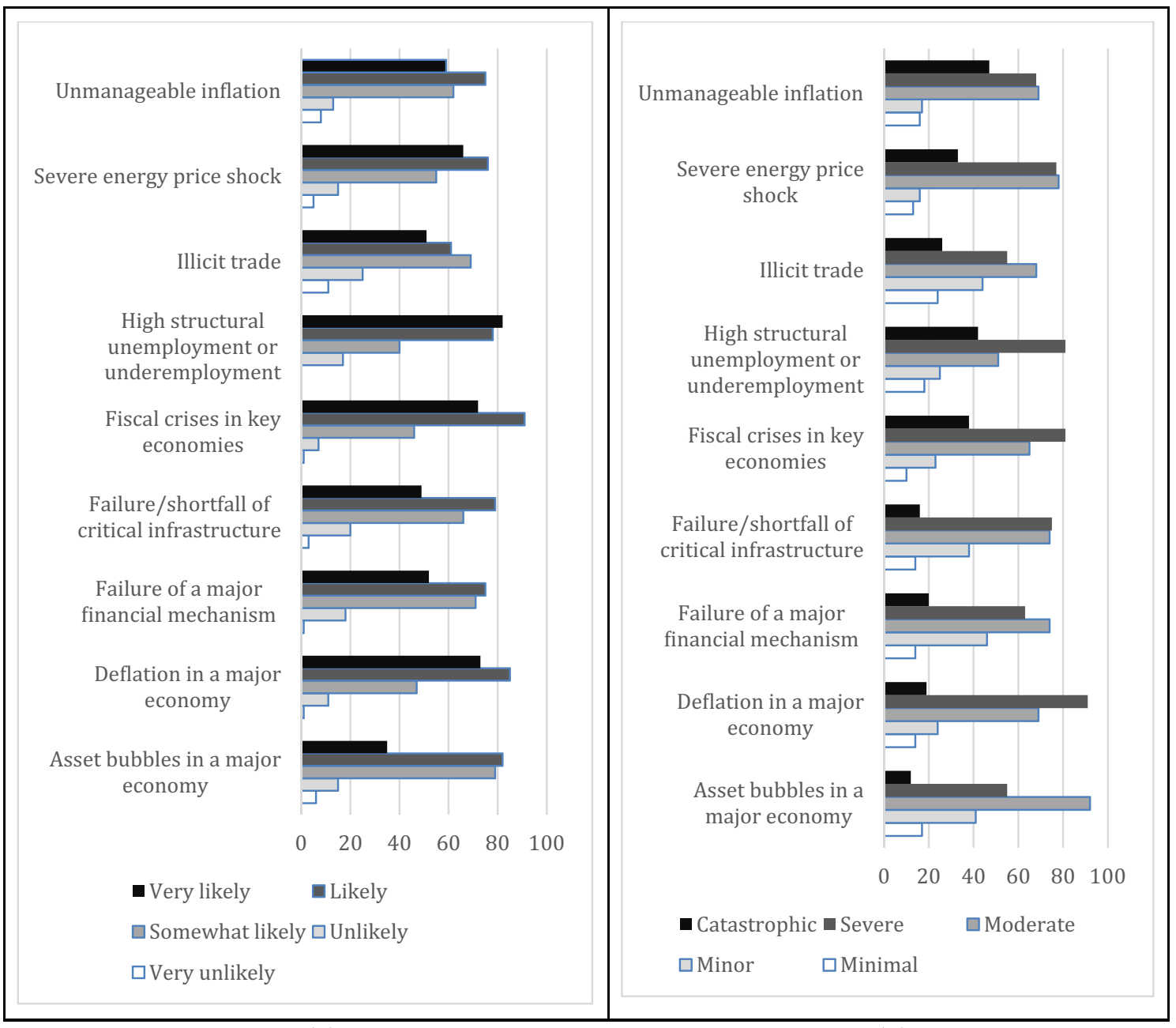

(a)

(b)

Fig. 1 Stated likelihoods (a) and consequences (b) of the global economic risks by the surveyed small and medium enterprises in Turkey 


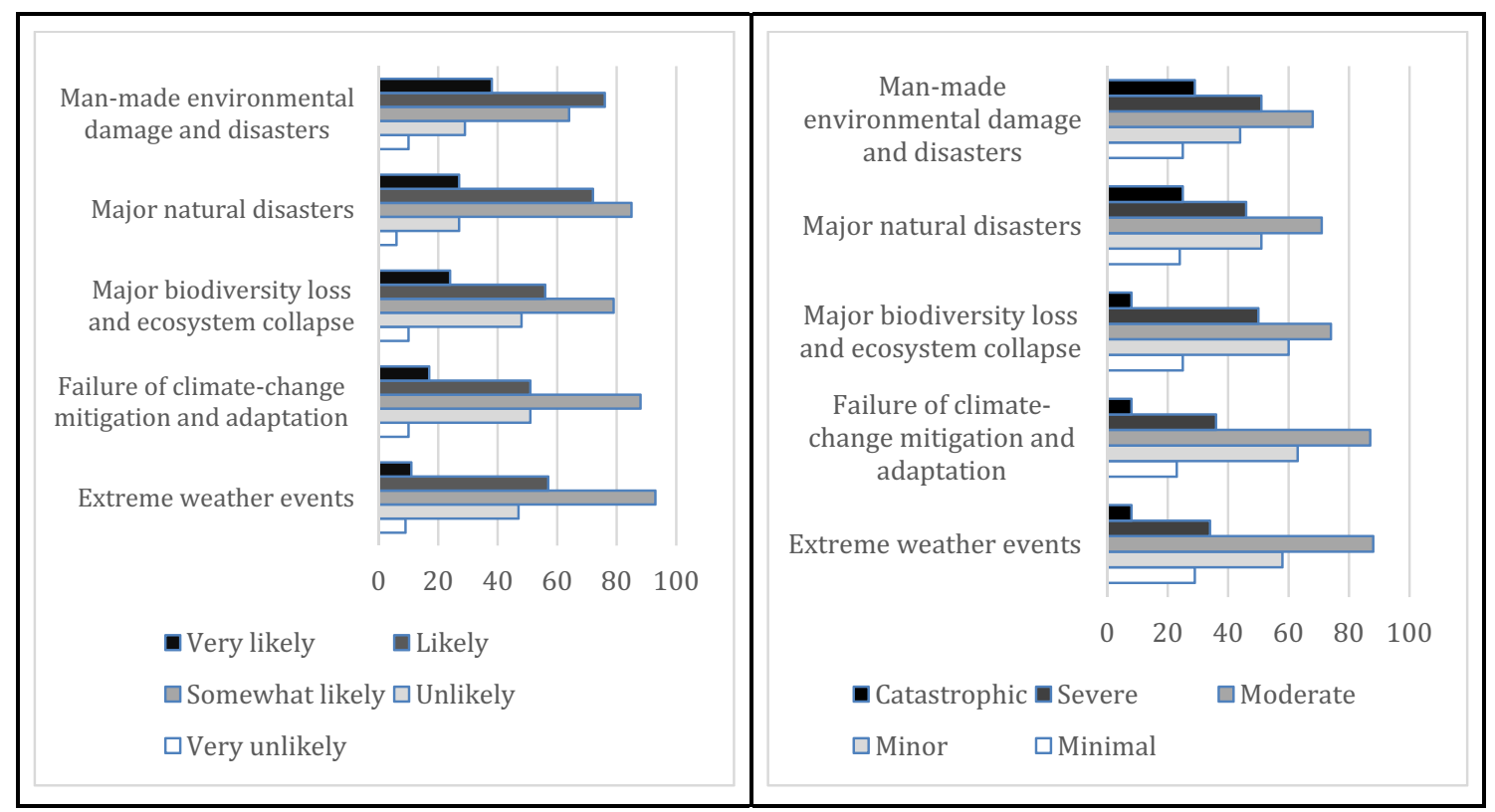

(a)

(b)

Fig. 2 Stated likelihoods (a) and consequences (b) of the global environmental risks by the surveyed small and medium enterprises in Turkey

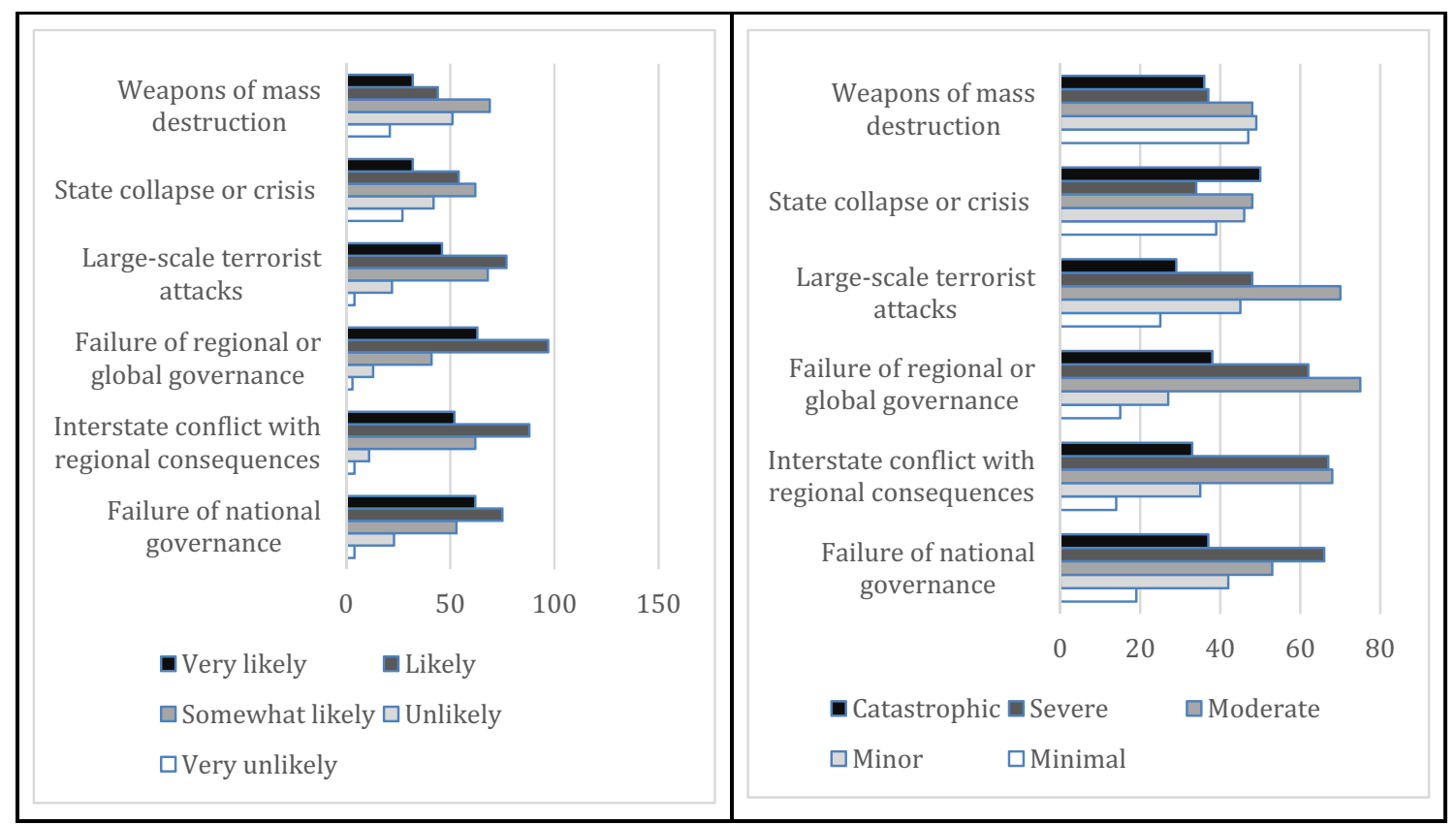

(a)

(b)

Fig. 3 Stated likelihoods (a) and consequences (b) of the global geopolitical risks by the surveyed small and medium enterprises in Turkey

not see it as having severe or catastrophic impacts on their operations.

Figure $5 \mathrm{a}$ and $\mathrm{b}$ present the stated likelihoods and consequences of the global technological risks. While the likelihood of all these risks is perceived to be high, largescale cyber-attacks and large data fraud are among the top in this risk group. Although the means of the impacts are lower for most of these risks, except for the negative consequences of technological developments, more SMEs stated that the consequences of large-scale cyber-attacks and large-scale data fraud are expected to be severe and catastrophic. 


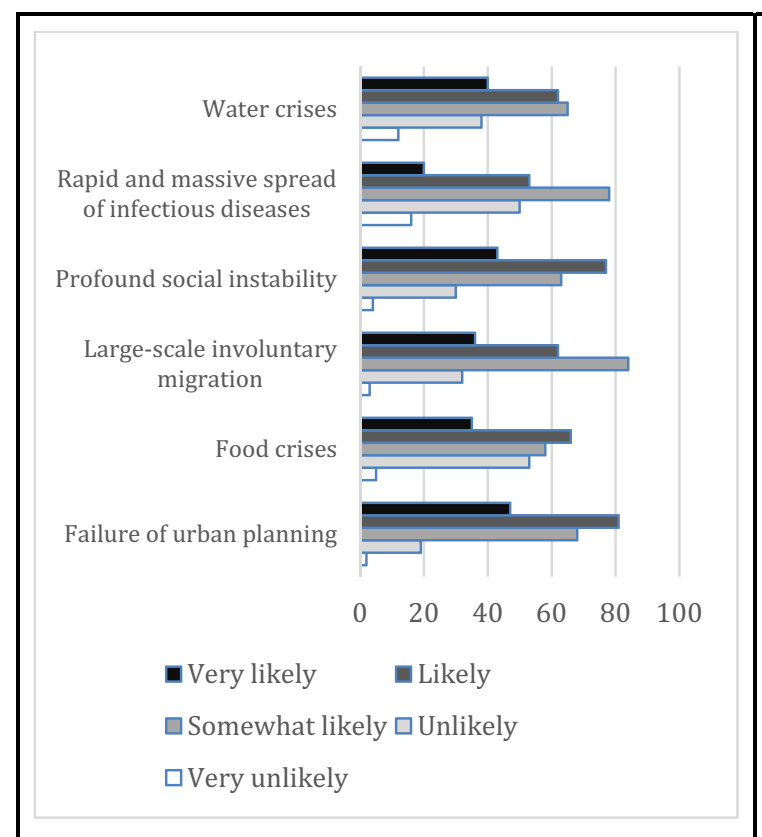

(a)

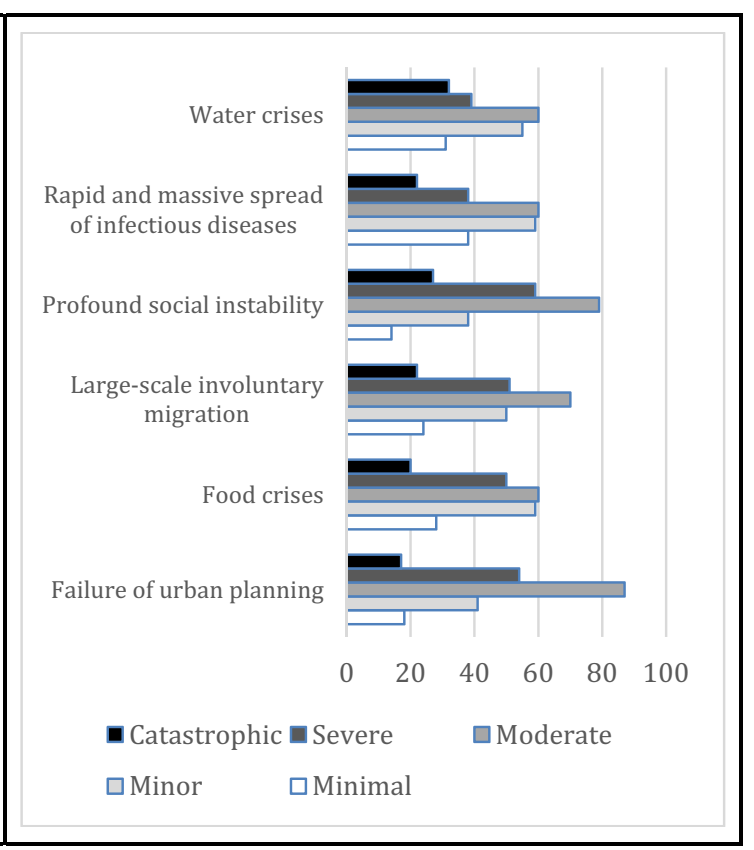

(b)

Fig. 4 Stated likelihoods (a) and consequences (b) of the global societal risks by the surveyed small and medium enterprises in Turkey

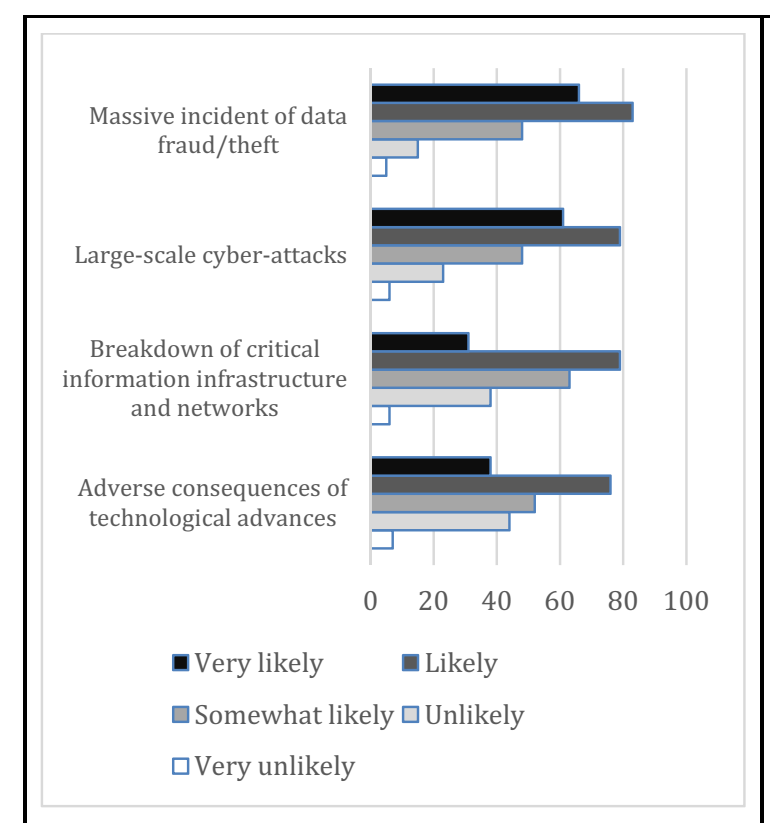

(a)

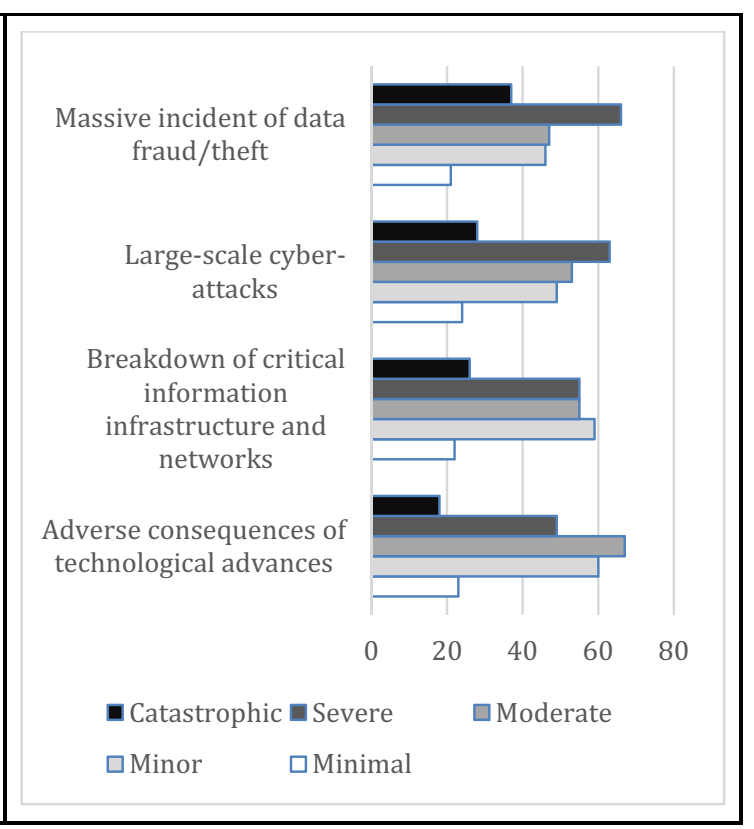

(b)

Fig. 5 Stated likelihoods (a) and consequences (b) of the global technological risks by the surveyed small and medium enterprises in Turkey

\subsection{Risk Values}

Risks can be calculated as the multiplication of likelihood by impacts (Table 2).

Using the mean values of each risk category, economic and technological risks are perceived to have the highest likelihood levels followed by geopolitical risks (Fig. 6a).
In terms of impacts, however, economic risks and geopolitical risks take the first and second ranks followed by technological risks. Societal and environmental risks are considered to have lower impacts (Fig. 6b). In terms of the overall risk, the results show that economic risks and geopolitical risks take the first and second place, followed by technological risks (Fig. 6c). 
Table 2 Mean likelihood and impact of global risks as perceived by the surveyed small and medium enterprises in Turkey $(\mathrm{N}=217)$

\begin{tabular}{|c|c|c|c|c|c|}
\hline Risk category & Risk & Likelihood & Impact & Risk $=$ likelihood $\times$ impact & Rank \\
\hline \multirow[t]{9}{*}{ Economic } & Asset bubbles in a major economy & 3.58 & 3.02 & 10.8 & 16 \\
\hline & Deflation in a major economy & 4 & 3.35 & 13.4 & 3 \\
\hline & Failure of a major financial mechanism & 3.73 & 3.13 & 11.7 & 11 \\
\hline & Failure/shortfall of critical infrastructure & 3.7 & 3.19 & 11.8 & 8 \\
\hline & Fiscal crises in key economies & 4.04 & 3.53 & 14.3 & 1 \\
\hline & High structural unemployment or underemployment & 4.04 & 3.48 & 14.1 & 2 \\
\hline & Illicit trade & 3.53 & 3.07 & 10.8 & 17 \\
\hline & Severe energy price shock & 3.84 & 3.47 & 13.3 & 4 \\
\hline & Unmanageable inflation & 3.76 & 3.52 & 13.2 & 6 \\
\hline \multirow[t]{5}{*}{ Environmental } & Extreme weather events & 3.06 & 2.7 & 8.3 & 30 \\
\hline & Failure of climate-change mitigation and adaptation & 3.06 & 2.74 & 8.4 & 28 \\
\hline & Major biodiversity loss and ecosystem collapse & 3.17 & 2.8 & 8.9 & 26 \\
\hline & Major natural disasters & 3.4 & 2.99 & 10.2 & 21 \\
\hline & Man-made environmental damage and disasters & 3.47 & 3.07 & 10.7 & 18 \\
\hline \multirow[t]{6}{*}{ Geopolitical } & Failure of national governance & 3.77 & 3.28 & 12.4 & 10 \\
\hline & Interstate conflict with regional consequences & 3.8 & 3.32 & 12.6 & 7 \\
\hline & Failure of regional or global governance & 3.94 & 3.37 & 13.3 & 5 \\
\hline & Large-scale terrorist attacks & 3.64 & 3.05 & 11.1 & 15 \\
\hline & State collapse or crisis & 3.1 & 3.05 & 9.5 & 25 \\
\hline & Weapons of mass destruction & 3.07 & 2.84 & 8.7 & 27 \\
\hline \multirow[t]{6}{*}{ Societal } & Failure of urban planning & 3.7 & 3.05 & 11.3 & 14 \\
\hline & Food crises & 3.34 & 2.88 & 9.6 & 24 \\
\hline & Large-scale involuntary migration & 3.44 & 2.99 & 10.3 & 20 \\
\hline & Profound social instability & 3.58 & 3.22 & 11.5 & 13 \\
\hline & Rapid and massive spread of infectious diseases & 3.05 & 2.76 & 8.4 & 29 \\
\hline & Water crises & 3.37 & 2.94 & 9.9 & 22 \\
\hline \multirow[t]{4}{*}{ Technological } & Adverse consequences of technological advances & 3.43 & 2.9 & 9.9 & 23 \\
\hline & Breakdown of critical information infrastructure and networks & 3.42 & 3.02 & 10.3 & 19 \\
\hline & Large-scale cyber-attacks & 3.76 & 3.1 & 11.7 & 12 \\
\hline & Massive incident of data fraud/theft & 3.88 & 3.24 & 12.6 & 9 \\
\hline
\end{tabular}

Table 3 Top 10 global risks in terms of likelihoods and impacts for the sample small and medium enterprises in Turkey

\begin{tabular}{lll}
\hline Rank & Likelihood & Impact \\
\hline 1 & Fiscal crises in key economies & Fiscal crises in key economies \\
2 & High structural unemployment or underemployment & Unmanageable inflation \\
3 & Deflation in a large economy & High structural unemployment or underemployment \\
4 & Interstate conflict with regional consequences & Severe energy price shock \\
5 & Massive incident of data fraud/theft & Interstate conflict with regional consequences \\
6 & Severe energy price shock & Deflation in a large economy \\
7 & Failure of regional or global governance & Failure of regional or global governance \\
8 & Failure of national governance & Failure of national governance \\
9 & Unmanageable inflation & Massive incident of data fraud/theft \\
10 & Large-scale cyber-attacks & Profound social instability \\
\hline
\end{tabular}




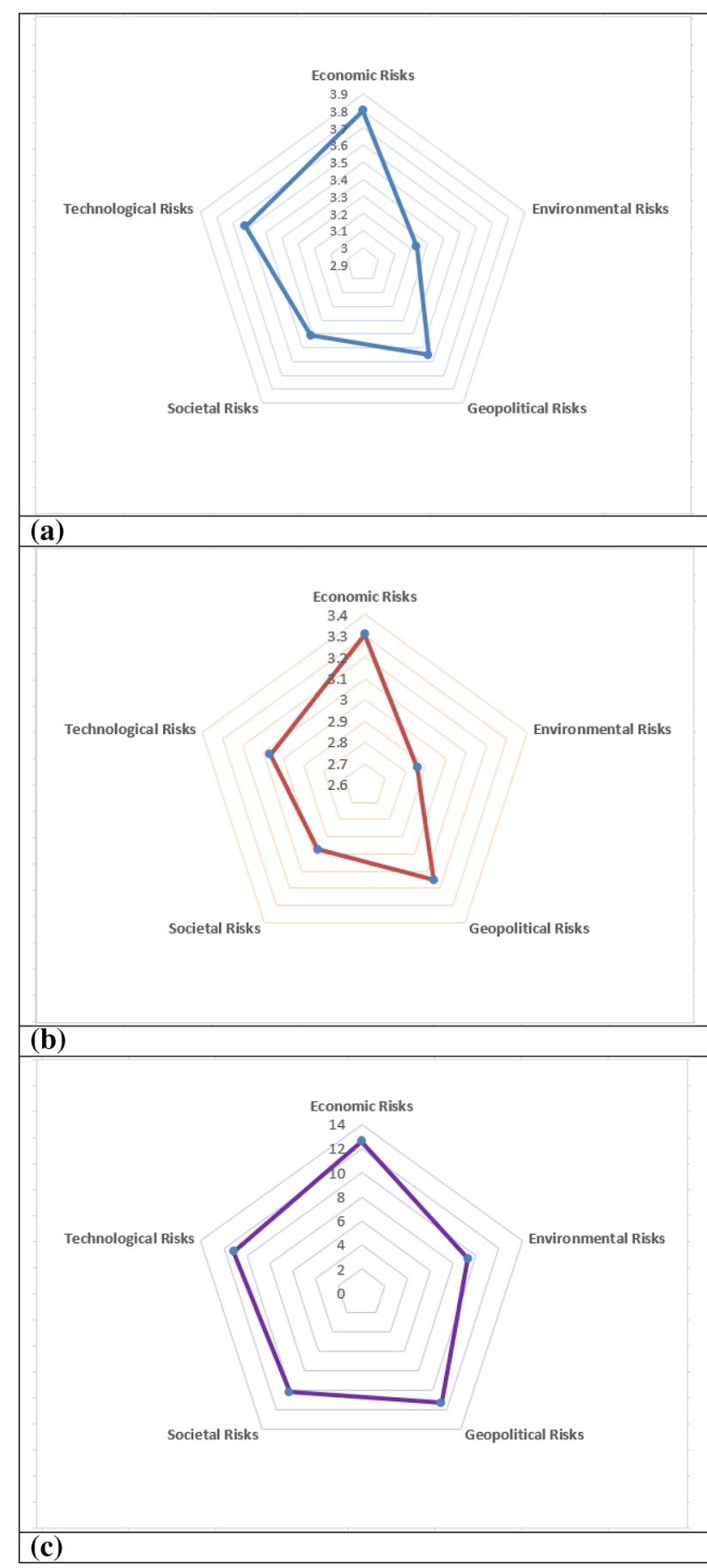

Fig. 6 Radar diagram for global risk likelihoods (a), risk impacts (b), and risk values (likelihood $\times$ impact) $(\mathbf{c})$ perceived by the surveyed small and medium enterprises in Turkey

\subsection{Risk Matrix}

Using the qualitative risk analysis methodology and perceived likelihood and impact data, a risk matrix was generated. Although the horizontal and vertical axes take the values 1 to 5 , the matrix axes have been rescaled for better visualization. This risk matrix displays the means of stated likelihoods and consequences for each risk. Risks at the top right and in the red colored area are risks with higher than average likelihoods and consequences. Risks in the lower left part of the matrix and colored green are considered to be low.

Figure 7 presents the resulting risk matrix for the 217 businesses and the 30 risks. Most economic risks are in the upper part of the risk matrix, followed by some geopolitical risks. Large-scale data fraud is the only technological risk that falls into the same area. Majority of environmental and societal risks, although scattered diagonally in the risk matrix, are in the lower part of the matrix.

\section{Discussion}

This study examined the global risks from the perspective of manufacturing SMEs with global footprints in the emerging economy of Turkey. The main aim was to understand whether and to what extent country- and industry-specific contexts and conditions affect SMEs perceptions of the global risks. Key findings are discussed here.

First, overall the results suggest that regardless of the ranking, the global risks are of high concern for SMEs in Turkey. The average likelihood for all global risks is 3.56 and the average impact is 3.1. The minimum perceived likelihood (infectious desease) is 3.05 and the minimum perceived impact (severe weather events) is 2.7. These figures confirm that all global risks are of concern for the SMEs and have significant implications for them, particularly those in the manufacturing sector (Zheng et al. 2010).

Second, findings indicate that the SMEs' perceived risks at the country level (Turkey) significantly varied from those perceived by the global companies in the global risk report (World Economic Forum 2019) (Table 3). While this study does not examine the underlying causes of these differences, it is evident that the SMEs' major concerns are global economic and geopolitical risks, both in terms of the likelihoods and the impacts. Individual SMEs in Turkey have been exposed and impacted more by the global economic risks than other risks. Our findings are consistent with a few different but related research conducted by Gül et al. (2010), Topçu (2013), and Deloitte (2017) that economic and financial risks such as devaluation of the Turkish Lira, interest rate risk, breakdown in cash flow or liquidity risk, credit risk, and increase in input prices were the key risks that businesses are facing in Turkey.

Third, it is not surprising that SMEs' highest perceived risks are economic and geopolitical risks. Studies demonstrate that financial and economic crises cause substantial 


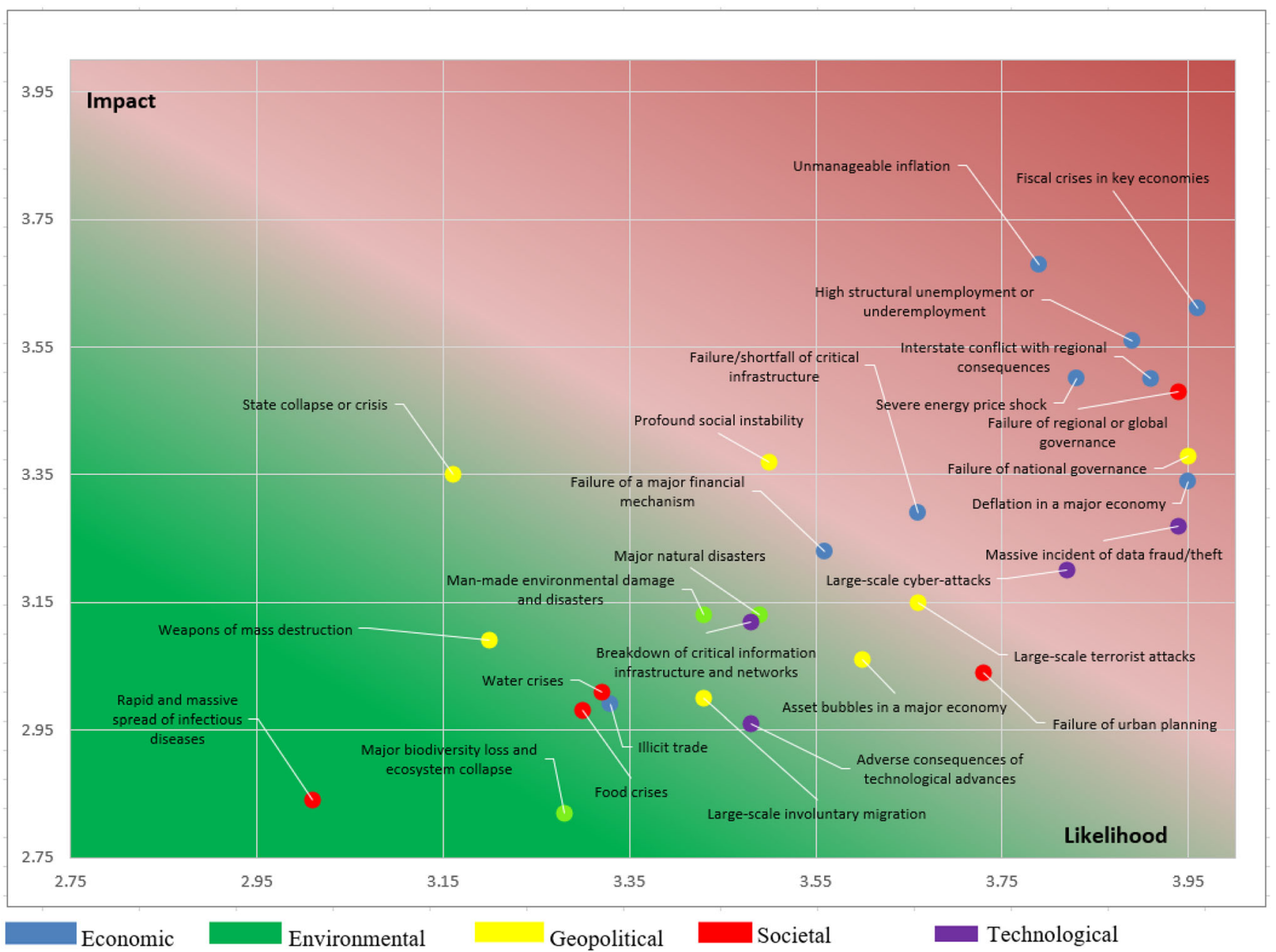

Fig. 7 Risk matrix for the sample small and medium enterprises in Turkey

downturn in the formation of new SMEs and the performance and survival of the existing ones in the market (Gregory et al. 2002; Zheng et al. 2010; Chowdhury 2011; Filardo 2011; Kossyva et al. 2014). Small and medium enterprises are very vulnerable to economic and financial crises as they are forced to close, downsize, and reduce the number of new ventures due to sharp decrease in demand and revenues (Ates et al. 2013; Sannajust 2014; Wehinger 2014). In today's global economy, Turkish SMEs are not exempt from this, and they have been frequently impacted by such risks in the past two decades as well (Karadag 2016). Moreover, giving high likelihood and high impact values for financial crises and other economic risks can be explained by the fact that Turkish economy has deficit in international trade (Abbasoğlu et al. 2019) and highly rely on external energy sources such as oil and natural gas.

Fourth, failure of regional or global governance and failure of national governance are the geopolitical risks that are among the top perceived risks by the SMEs in this study. These risks have been largely felt by Turkish SMEs in recent years. Turkey has been in close proximity to a number of regional conflicts with potential impacts on the SMEs (Omay et al. 2013; Bilgel and Karahasan 2017) and because of their vulnerability (Pascual-Ramsay 2015) and awareness of these risks, such risks are perceived highly both in terms of the likelihoods and the impacts.

Fifth, the sample SMEs also consider the likelihood of large data fraud/theft and large-scale cyber-attacks to be high. This is possibly due to the increasing dependency of the SMEs to the internet and the increasing number of cyber attacks and data theft in recent years (Mbuyisa and Leonard 2017). While SMEs do not consider the impacts of these risks as high as their likelihoods, still these risks can cause disruptions and severe consequences to them, particularly because they are not well equipped to manage these risks. A recent report published by Allianz (2019) confirms that SMEs in Turkey increasingly recognize their cyber vulnerability and risks. 
Finally, the relatively lower perceived likelihoods and impacts of the global risks by the sample SMEs can be attributed to the fact that small businesses may not be directly and highly impacted by distance environmental risks such as major natural hazard-induced disasters and that the awareness about some of the environmental risks among the SMEs may be lower than other risks. Moreover, Turkey has not experienced a major natural hazard-induced disaster in the past 20 years, and major weather events have been very local.

\section{Conclusion}

The results of this study indicate the importance of addressing global risk assessments by SMEs. As more and more SMEs are connected with the national and global economies, their awareness about theses risks and the impacts that they could have for them will increase. This awareness can help SMEs to take these risks into consideration and prepare themselves for such risks. This study highlighted that SMEs' perceptions of the global risks are different from the businesses that operate at large scale at the global level. It also demonstrated that country's circumstances can affect SMEs' assessments of the likelihood, impacts, and rankings of global risks. It demonstrated that SMEs are more concerned about economic risks and risks that directly impact economic systems and variables, particularly geopolitical risks. Environmental risks, while important, are not at the top of the list for SMEs. Considering the significant role that SMEs play in local and national economies and the fact that they are concerned most about global economic and geopolitical risks, it can be argued that efforts towards lowering global economic and geopolitical risks can significantly benefit SMEs.

Since Turkey's SMEs have been in a relatively unique situation in the past two decades with respect to some of the major global risks, similar studies in countries in other parts of the world may shed more light on how country contexts and type and size of businesses impact SMEs' perceptions of global risks. It was beyond the scope of this study to examine the SMEs' risk and business continuity actions taken to manage and mitigate the risks. Future studies can also investigate whether and how SMEs prepare themselves for global risks.

Acknowledgements This research has been partially supported by the Scientific and Technological Research Council of Turkey (TUBITAK) through the 2221-Fellowship Program for Visiting Scientists and Scientists on Sabbatical Leave. The project has been also supported in part by York University's Advanced Disaster, Emergency, and Rapid response Simulation (ADERSIM) funded by Ontario Research Fund.
Open Access This article is licensed under a Creative Commons Attribution 4.0 International License, which permits use, sharing, adaptation, distribution and reproduction in any medium or format, as long as you give appropriate credit to the original author(s) and the source, provide a link to the Creative Commons licence, and indicate if changes were made. The images or other third party material in this article are included in the article's Creative Commons licence, unless indicated otherwise in a credit line to the material. If material is not included in the article's Creative Commons licence and your intended use is not permitted by statutory regulation or exceeds the permitted use, you will need to obtain permission directly from the copyright holder. To view a copy of this licence, visit http://creativecommons. org/licenses/by/4.0/.

\section{References}

Abadie, A., and J. Gardeazabal. 2008. Terrorism and the world economy. European Economic Review 52(1): 1-27.

Abbasoğlu, O.F., A. İmrohoroğlu, and A. Kabukçuoğlu. 2019. The Turkish current account deficit. Economic Inquiry 57(1): $515-536$.

Alegre, J., and R. Chiva. 2013. Linking entrepreneurial orientation and firm performance: The role of organizational learning capability and innovation performance. Journal of Small Business Management 51(4): 491-507.

Allianz. 2019. Allianz risk baromter 2019 SME business risks. https:// www.agcs.allianz.com/news-and-insights/expert-risk-articles/ risk-barometer-2019-sme-business-risks.html. Accessed 21 Jan 2020.

Araz-Takay, B., K.P. Arin, and T. Omay. 2009. The endogenous and non-linear relationship between terrorism and economic performance: Turkish evidence. Defence and Peace Economics 20(1): $1-10$.

Asgary, A., and A.I. Ozdemir. 2019. Global risks and tourism industry in Turkey. Quality \& Quantity. https://doi.org/10.1007/s11135019-00902-9.

Asgary, A., M.I. Anjum, and N. Azimi. 2012. Disaster recovery and business continuity after the 2010 flood in Pakistan: Case of small businesses. International Journal of Disaster Risk Reduction 2: 46-56.

Asgary, A., N. Azimi, and M.I. Anjum. 2013. Measuring small businesses disaster resiliency: Case of small businesses impacted by the 2010 flood in Pakistan. International Journal of Business Continuity and Risk Management 4(2): 170-187.

Ates, A., P. Garengo, P. Cocca, and U. Bititci. 2013. The development of SME managerial practice for effective performance management. Journal of Small Business and Enterprise Development 20(1): 28-54.

Auzzir, Z., R. Haigh, and D. Amaratunga. 2018. Impacts of disaster to SMEs in Malaysia. Procedia Engineering 212: 1131-1138.

Ballesteros, M.M., and D.N. Sonny. 2015. Building Philippine SMEs resilience to natural disasters. PIDS discussion paper series, No. 2015-20. Makati: Philippine Institute for Development Studies (PIDS).

Bao, C., D. Wu, J. Wan, J. Li, and J. Chen. 2017. Comparison of different methods to design risk matrices from the perspective of applicability. Procedia Computer Science 122: 455-462.

Bilgel, F., and B.C., Karahasan. 2017. The economic costs of separatist terrorism in Turkey. Journal of Conflict Resolution 61(2): 457-479.

Briozzo, A., and C. Cardone-Riportella. 2012. Evaluating the impact of public programs of financial aid to SMEs during times of crisis: The Spanish experience. Working Papers 12.04. Seville, 
Spain: Department of Financial Economics and Accounting, Universidad Pablo de Olavide.

Brustbauer, J. 2016. Enterprise risk management in SMEs: Towards a structural model. International Small Business Journal 34(1): $70-85$.

Cefis, E., and O. Marsili. 2006. Survivor: The role of innovation in firms' survival. Research Policy 35(5): 626-641.

Chacko, J.G., and G. Harris. 2006. Information and communication technology and small, medium, and micro Enterprises in AsiaPacific - size does matter. Information Technology for Development 12(2): 175-177.

Chatterjee, R., K. Shiwaku, R.D. Gupta, G. Nakano, and R. Shaw. 2015. Bangkok to Sendai and beyond: Implications for disaster risk reduction in Asia. International Journal of Disaster Risk Science 6(2): 177-188.

Chatterjee, R., N. Ismail, and R. Shaw. 2016. Identifying priorities of Asian small- and medium-scale enterprises for building disaster resilience. In Urban disasters and resilience in Asia, ed. R. Shaw, A.S. Atta-ur-Rahman, A. Surjan, and G.A. Parvin, 179-194. Oxford: Butterworth-Heinemann.

Chowdhury, S.R. 2011. Impact of global crisis on small and medium enterprises. Global Business Review 12(3): 377-399.

Cox, A.L. 2008. What's wrong with risk matrices? Risk Analysis 28(2): 497-512.

Crichton, D. 2006. Climate change and its effects on small businesses in the UK. London: AXA Insurance UK.

Deloitte. 2017. European CFO survey. http://financedocbox.com/ Investing/71637212-Deloitte-seb-cfo-survey-comparisonbetween-nordic-and-european-cfos.html. Accessed 31 Jan 2020.

European Commission. 2015. Annual report on European SMEs 2014/2015. Brussels: European Commission.

Ezgi, O. 2014. The role of lifeline losses in business continuity in the case of Adapazari, Turkey. Environmental Hazards 13(4): 298-312.

Filardo, A. 2011. The impact of the international financial crisis on Asia and the Pacific: Highlighting monetary policy challenges from a negative asset price bubble perspective. Bank for International Settlements Working Paper No. 356, Monetary and Economic Department.

Gagliardi-Main, D., P. Muller, E. Glossop, C. Caliandro, M. Fritsch, G. Brtkova, N.U. Bohn, D. Klitou, et al. 2013. Annual report on European SMEs 2012/2013: A recovery on the horizon? Brussels: European Commission.

Gasbarro, F., F. Rizzi, and M. Frey. 2018. Sustainable institutional entrepreneurship in practice. International Journal of Entrepreneurial Behavior \& Research 24(2): 476-498.

Gregory, G., C. Harvie, and H.H. Lee. 2002. Korean SMEs in the wake of the financial crisis: Strategies, constraints, and performance in a global economy. Australia: Department of Economics, University of Wollongong. https://ro.uow.edu.au/ commwkpapers/58. Accessed 13 Jan 2020.

Gül, H., T. Kandemir, and E. Çakır. 2010. Risk and uncertainity expectations in SMEs: The case of Karaman. Afyon Kocatepe University Social Science Journal 12(2): 119-144 (in Turkish).

Gunawansa, A., and H.W. Kua. 2014. A comparison of climate change mitigation and adaptation strategies for the construction industries of three coastal territories. Sustainable Development 22(1): 52-62.

Güneş, Ş., and S. Teker. 2010. Awareness of corporate risk management in Turkish energy industry. Journal of Doğuş University 11(1): 64-76 (in Turkish).

Halkos, G., A. Skouloudis, C. Malesios, and K. Evangelinos. 2018. Bouncing back from extreme weather events: Some preliminary findings on resilience barriers facing small and medium-sized enterprises. Business Strategy and the Environment 27(4): $547-559$
Han, Z., and J. Nigg. 2011. The influences of business and decision makers' characteristics on disaster preparedness-A study on the 1989 Loma Prieta Earthquake. International Journal of Disaster Risk Science 2(4): 22-31.

Hopkin, P. 2012. Fundamentals of risk management: Understanding, evaluating and implementing, 2nd edn. London: Kogan Page.

Igwe, P.A., A.N. Amaugo, O.M. Ogundana, O.M. Egere, and J.M. Anigbo. 2018. Factors affecting the investment climate, SMEs productivity and entrepreneurship in Nigeria. European Journal of Sustainable Development 7(1): 182-200.

IPCC (Intergovernmental Panel on Climate Change). 2013. Climate change 2013: The physical science basis. Contribution of working group I to the fifth assessment report of the Intergovernmental Panel on Climate Change. Cambridge: Cambridge University Press.

Karadag, H. 2016. The role of SMEs and entrepreneurship on economic growth in emerging economies within the post-crisis era: An analysis from Turkey. Journal of Small Business and Entrepreneurship Development 4(1): 22-31.

Kaya, H.P., and S. Uzay. 2017. The risks that will threaten going concern and control recommendations: Case study on SMEs. The Journal of Accounting and Finance, Special Issue: 46-64.

Kilian, L. 2008. A comparison of the effects of exogenous oil supply shocks on output and inflation in the G7 countries. Journal of the European Economic Association 6(1): 78-121.

Kossyva, D., K. Sarri, and N. Georgopoulos. 2014. Co-opetition: A business strategy for SME in times of economic crisis. SouthEastern Europe Journal of Economics 1: 89-106.

Kuo, H.I., C.C. Chen, W.C. Tseng, L.F. Ju, L.F. and B.W. Huang. 2008. Assessing impacts of SARS and avian flu on international tourism demand to Asia. Tourism Management 29(5): 917-928.

Leopoulos, V.N., K.A. Kirytopoulos, and C. Malandrakis. 2006. RM for SMEs: Tools to use and how. Production Planning \& Control 17(3): 322-332.

Linnenluecke, M.K., and A. Griffiths. 2010. Beyond adaptation: Resilience for business in light of climate change and weather extremes. Business \& Society 49(3): 477-511.

Linnenluecke, M.K., and A. Griffiths. 2012. Assessing organizational resilience to climate and weather extremes: Complexities and methodological pathways. Climatic Change 113(3-4): 933-947.

Marks, D., and F. Thomalla. 2017. Responses to the 2011 floods in central Thailand: Perpetuating the vulnerability of small and medium enterprises? Natural Hazards 87(2): 1147-1165.

Mbuyisa, B., and A. Leonard. 2017. The role of ICT use in SMEs towards poverty reduction: A systematic literature review. Journal of International Development 29(2): 159-197.

Mekinc, J., T. Kociper, and B. Dobovsek. 2013. The impact of corruption and organized crime on the development of sustainable tourism. Journal of Criminal Justice and Security 15(2): 218-239.

Modarres, M. 2006. Risk analysis in engineering: Techniques, tools, and trends. New York: CRC Press.

Mulhall, R.A., and J.R. Bryson. 2014. Energy price risk and the sustainability of demand side supply chains. Applied Energy 123: 327-334.

Ni, H., A. Chen, and N. Chen. 2010. Some extensions on risk matrix approach. Safety Science 48(10): 1269-1278.

OECD (Organisation for Economic Co-operation and Development). 2000. Economic effects of the 1999 Turkish Earthquakes: An interim report. OECD Economics Department working paper no. 247. Paris: OECD.

OECD (Organisation for Economic Co-operation and Development). 2014. Financing SMEs and entrepreneurs 2014: An OECD scoreboard. Paris: OECD Publishing. 
Omay, T., B. Araz-Takay, A. Eruygur, and I. Kilic. 2013. The effects of terrorist activities on foreign direct investment: Nonlinear evidence from Turkey. Review of Economics 64(2): 139-158.

Onur, B.F. 2018. Turkey: A crossroads of risk and opportunities. http://www.hurriyetdailynews.com/turkey-a-crossroads-of-riskand-opportunities-136068. Accessed 08 Mar 2019.

Pascual-Ramsay, A. 2015. Global risks and EU businesses. In The global context: How politics, investment, and institutions impact European businesses, ed. J. Solana, and A. Saz-Carranza, 10-37. Barcelona, Spain: EsadeGeo.

Salgado-Gálvez, M.A. 2018. Estimating the lost economic production caused by internal displacement because of disasters. International Journal of Disaster Risk Science 9(4): 496-506.

Sannajust, A. 2014. Impact of the world financial crisis to SMEs: The determinants of bank loan rejection in Europe and USA (IPAG Working Paper No. 2014-327). Paris: IPAG Business School (Institut de préparation à l'administration et à la gestion). http:// www.ipagen.com/wp-content/uploads/recherche/WP/IPAG_ WP_2014_327.pdf. Accessed 13 Jan 2020.

Schaefer, A., S. Williams, and R. Blundel. 2011. SMEs' construction of climate change risks: The role of networks and values. In Proceedings of International Conference on SMEs: Moving Towards Sustainable Development, 20-22 October 2011, Montreal, Canada. 1-18.

Sharma M.K., and R. Bhagwat. 2006. Practice of information systems: Evidence from select Indian SMEs. Journal of Manufacturing Technology Management 17(2): 199-223.

Snyder, L.V., and Z.J.M Shen. 2006. Supply chain management under the threat of disruptions. The Bridge 36: 39-45.

Talbot, J. 2011. What's right with risk matrices? A great tool for risk managers. Version 1, 31000 risk, 9 April 2011. https://31000risk. wordpress.com/article/what-s-right-with-risk-matrices-3dksezem jiq54-4/. Accessed 13 Jan 2020.

Topçu, B. 2013. Corporate risk management in businesses. İstanbul Chamber of Trade Publications. No. 2013-19, Istanbul (in Turkish).

Tumen, S. 2016. The economic impact of Syrian refugees on host countries: Quasi-experimental evidence from Turkey. American Economic Review 106(5): 456-460.

TÜRSAB and TUADER (Association of Turkish Travel Agencies and Turkish Association of Tourism Academicians). 2017.
Tourism industry report, 2017 January-July term. https://www. tursab.org.tr/tr/tursabdan-haberler/kurumsal-haberler/tursab-tua der-turizmsektor-raporu-yayinlandi_16736.html. Accessed 13 Jan 2020 (in Turkish).

UNDP (United Nations Development Programme). 2013. Small businesses: Impact of disasters and building resilience: Analysing the vulnerability of micro, small, and medium enterprises to natural hazards and their capacity to act as drivers of community recovery. Background paper for the global assessment report on disaster risk reduction 2013. New York: UNDP.

Watkins, R.E., F.C. Cooke, R.J. Donovan, C.R. MacIntyre, R. Itzwerth, and A.J. Plant. 2008. Tackle the problem when it gets here: Pandemic preparedness among small and medium businesses. Qualitative Health Research 18(7): 902-912.

Wedawatta, G., B. Ingirige, and D. Amaratunga. 2010. Building up resilience of construction sector SMEs and their supply chains to extreme weather events. International Journal of Strategic Property Management 14(4): 362-375.

Wehinger, G. 2014. SMEs and the credit crunch: Current financing difficulties, policy measures and a review of literature. $O E C D$ Journal: Financial Market Trends 2: 115-148.

Weinhofer, G., and T. Busch. 2013.Corporate strategies for managing climate risks. Business Strategy and the Environment 22(2): 121-144.

World Economic Forum. 2019. The global risks report 2019. Geneva: World Economic Forum.

Ye, L., and M. Abe. 2012. The impacts of natural disasters on global supply chains. ARTNeT working paper series, No. 115. Bangkok: Asia-Pacific Research and Training Network on Trade (ARTNeT).

Yoshino, N., and F. Taghizadeh-Hesary. 2018. The role of SMEs in Asia and their difficulties in accessing finance. Asian Development Bank Institute. http://hdl.handle.net/11540/9483. Accessed 31 Jan 2020.

Yuwen, H., X. He, X. Qian, and M. Yuan. 2016. Controlling town industry explosion hazard in China. International Journal of Disaster Risk Science 7(4): 440-444.

Zheng, S., M.E. Kahn, and H. Liu. 2010. Towards a system of open cities in China: Home prices, FDI flows and air quality in 35 major cities. Regional Science and Urban Economics 40(1): $1-10$. 